\title{
PENGARUH METODE DRILL BERBANTUAN SOAL ANIMASI TERHADAP KEMAMPUAN BERPIKIR REFLEKTIF SISWA PADA KONSEP DINAMIKA PARTIKEL.
}

\author{
Shinta Fitriyani ${ }^{1, a)}$, Erina Hertanti ${ }^{2, \text { b) }}$, Ai Nurlaela ${ }^{3, c)}$ \\ 1.Pendidikan Fisika UIN Syarif Hidayatullah Jakarta \\ 2.Pendidikan Fisika UIN Syarif Hidayatullah Jakarta \\ ${ }^{3}$ Pendidikan Fisika UIN Syarif Hidayatullah Jakarta
}

Email: a)shintafitriyani@gmail.com, b)erina.hertanti@uinjkt.ac.id, ${ }^{c}$ ai.nurlaela@uinjkt.ac.id

\begin{abstract}
Abstrak
Penelitian ini bertujuan untuk membuktikan pengaruh metode drill berbantuan soal animasi terhadap kemampuan berpikir reflektif siswa pada konsep dinamika partikel. Penelitian dilakukan pada bulan Februari 2016 di SMA Negeri 1 Karawang. Dalam penelitian ini terdapat dua sampel, yaitu kelas X MIPA 1 sebagai kelas kontrol dan kelas X MIPA 6 sebagai kelas eksperimen. Metode penelitian yang digunakan adalah quasi eksperiment dengan desain nonequivalent control group dan teknik pengambilan sampel berupa purposive sampling. Instrumen yang digunakan adalah instrumen tes berupa soal uraian dan instrumen nontes berupa angket. Berdasarkan hasil uji hipotesis dengan menggunakan uji-t terhadap data posttest diperoleh nilai thitung sebesar 2,00 dan nilai dan nilai $\mathrm{t}_{\text {tabel }}$ sebesar 1.99 , terlihat bahwa nilai $\mathrm{t}_{\text {hitung }}>\mathrm{t}_{\mathrm{tabe}}$, sehingga $\mathrm{H}_{0}$ ditolak. Artinya, metode drill berbantuan soal animasi terbukti berpengaruh terhadap kemampuan berpikir reflektif siswa.
\end{abstract}

Kata-kata Kunci: Metode Drill, Soal dalam format Animasi, Kemampuan Berpikir Reflektif

\begin{abstract}
This research aims to prove the effect of drill method by questions format with animation to reflective thinking skills students on the dynamic particle concept. The research was conducted on February 2016 in SMA Negeri 1 Karawang. This research has two samples, there were X MIPA 1 as control class and X MIPA 6 as experiment class. The research method was a quasi experiment with nonequivalent control group design and the sampling technique was purposive sampling. The instrument divided into two types, test with essay questions and non-test with the questionnaire. A hypothesis based on testing that used t-test to post test result the value of $t_{\text {count }}$ was 2.00 and table was 1,99 , that showed the value of $t_{\text {count }}>t_{\text {table, }}, s_{0} \mathrm{H}_{0}$ was rejected. It means, the drill method by questions format in the form of animation was proved the influence of reflective thinking skills students.
\end{abstract}

\section{PENDAHULUAN}

Berpikir merupakan suatu kemampuan yang dimiliki manusia dalam menggunakan akalnya untuk mengolah informasi. Kemampuan berpikir sangat penting dalam menyelesaikan masalah, sehingga perlu dikembangkan dalam proses pembelajaran. Kemampuan berpikir yang perlu dikembangkan pada abad ke 21 ini adalah kemampuan berpikir tingkat tinggi. Kemampuan berpikir tingkat tinggi (High Order Thingking) adalah kemampuan pikiran seseorang secara lebih luas untuk menemukan tantangan baru. Kemampuan berpikir ini membuat seseorang menerapkan informasi baru atau pengetahuan sebelumnya dalam menjangkau kemungkinan pada situasi yang baru (Rofiah, 2013). Kemampuan berpikir tingkat tinggi di Indonesia masih sangat rendah jika dibandingkan dengan 
negara lain. Hal ini bisa dilihat dari hasil salah satu studi internasional kemampuan kognitif siswa yaitu TIMSS (Trends in Mathematics and Science Study) yang diadakan oleh IEA (International Association for the Evaluation of Educational Achievement). Hasil TIMSS 2011 pada bidang Fisika menunjukkan Indonesia memperoleh nilai 397, sedangkan nilai rata-rata internasional yaitu 500. Berdasarkan data TIMSS, persentase kemampuan pemahaman siswa lebih tinggi dibandingkan dengan kemampuan penerapan dan penalaran (Rofiah, 2013). Kemampuan penerapan dan penalaran merupakan kemampuan tingkat tinggi, sedangkan kemampuan pemahaman merupakan bagian dari kemampuan tingkat dasar. Dengan demikian, data tersebut menunjukkan bahwa kemampuan berpikir dasar siswa lebih tinggi dibanding kemampuan berpikir tingkat tinggi.

Di dalam kemampuan berpikir tingkat tinggi terdapat beberapa kemampuan berpikir, diantaranya kemampuan berpikir reflektif. Paden (2008) mengatakan bahwa berpikir reflektif adalah "An analysis and making judgment about what has happened", suatu analisis dan membuat keputusan mengenai apa yang terjadi (Paden, 2008). Kemampuan berpikir reflektif ini merupakan suatu kemampuan berpikir yang sangat penting dalam pemecahan masalah. Proses berpikir reflektif dalam pemecahan masalah menurut Dewey merupakan proses pemecahan masalah yang membutuhkan keterampilan mengenali masalah, merumuskan masalah, menyusun beberapa alternatif pemecahannya, mengembangkan ide dari alternatif yang dipilih, serta keterampilan mempertimbangkan kembali keputusannya hingga menjadi keputusan final (Elianawati, D, \& J, 2013). Proses-proses dalam berpikir reflektif akan muncul ketika siswa menghadapi persoalan yang akan diselesaikan dengan cara menghubungkan pengetahuan yang telah diperoleh sebelumnya.

Dalam mengungkapkan kemampuan berpikir reflektif diperlukan suatu indikator untuk menentukan apakah seseorang sudah berpikir reflektif atau belum. Beberapa peneliti menurunkan indikator berpikir reflekif berdasarkan pembelajaran berpikir reflektif yang ditemukan. Berikut ini adalah indikator yang dikemukakan oleh para ahli. Hullfish dan Smith menyatakan pembelajaran reflektif meliputi: mengakui masalah, memberikan hipotesis, menguji tindakan berupa temuan yang dilanjutkan dengan ekslpanasi dan prediksi diikuti perivikasi (Hullfish \& Smith, 1961). Chen menemukan kerangka berpikir reflektif adalah 5R (Reflect, Recognition, Relaization, Response, Resolution) (Chen, 2012). Pada penelitian kali ini, indikator kemampuan berpikir reflektif yang digunakan terdiri dari enam indikator, yaitu mendeskripsikan, mengidentifikasi, menginterpretasi, mengevaluasi, memprediksi cara penyelesaian, dan membuat kesimpulan.

Jika siswa sudah memiliki kemampuan berpikir reflektif yang baik, maka kemampuan siswa dalam menyelesaikan masalah pun akan baik pula. Dalam hal ini, penyelesaian masalah yang biasanya dilatihkan di sekolah adalah dengan menyelesaikan soal-soal baik yang ada di buku maupun yang diberikan secara langsung oleh guru. Soal-soal yang diberikan oleh guru biasanya diajarkan melalui metode drill.

Metode drill atau metode latihan adalah suatu metode mengajar di mana siswa melakukan kegiatan latihan agar memiliki keterampilan yang lebih tinggi dari apa yang telah dipelajari (Roestiyah, 2012). Selain itu, metode drill juga merupakan sarana untuk menumbuhkan kebiasaankebiasaan yang baik (Djamarah \& Zain). Metode drill memiliki kelebihan, diantaranya adalah praktis, mudah dilakukan, dan dapat meningkatkan keterampilan siswa jika dilakukan secara teratur. Sementara, kelemahan dari metode drill adalah sedikit membosankan karena siswa diminta untuk berlatih terus menerus. Agar penggunaan metode drill maksimal, maka soal yang biasa digunakan dalam format cetak digantikan dengan menggunakan soal dalam format animasi. Soal dalam format animasi memiliki beberapa keuntungan, diantaranya adalah dapat menarik perhatian, memungkinkan visualisasi dari konsep imajinasi, objek dan hubungan-hubungannya (Purnama, 2013). Melalui kelebihan dan manfaat dari soal dalam format animasi, diharapkan dapat menjadi inovasi baru dalam penggunaan metode drill sehingga dapat meningkatkan kemampuan berpikir reflektif siswa.

Berdasarkan pemaparan di atas, maka dilakukan penelitian yang berjudul: "Pengaruh Metode Drill Berbantuan Soal Animasi terhadap Kemampuan Berpikir Reflektif Siswa pada Konsep Dinamika Partikel." Tujuannya adalah untuk membuktikan pengaruh metode drill berbantuan soal animasi terhadap Kemampuan Berpikir Reflektif siswa pada konsep dinamika partikel 


\section{METODE PENELITIAN}

Penelitian ini berlangsung pada bulan Februari tahun ajaran 2015-2016. Penelitian dilakukan di SMA Negeri 1 Karawang yang beralamat di Jalan Jenderal Ahmad Yani No. 22 Karawang Barat. Metode penelitian yang digunakan adalah metode quasi eksperiment dengan desain non equivalent control group design. Populasi yang diteliti adalah seluruh siswa di SMA Negeri 1 Karawang dengan populasi targetnya adalah seluruh siswa kelas X. Teknik pengambilan sampel yang digunakan adalah dengan purposive sampling. Sampel yang diambil adalah siswa kelas X MIA 6 sebagai kelas eksperimen yang diberikan pembelajaran dengan metode drill berbantuan soal dalam format animasi, sedangkan kelas X MIA 1 sebagai kelas kontrol dan pembelajarannya menggunakan pembelajaran konvensional. Instrumen yang digunakan pada penelitian ini adalah instrumen tes dan nontes. Instrumen tes yang digunakan berupa sepuluh soal uraian yang sebelumnya dilakukan uji validitas, reliabilitas, tingkat kesukaran dan daya pembeda. Instrumen tes diberikan kepada kelas kontrol dan kelas eksperimen. Instrumen nontes yang digunakan adalah berupa angket respon siswa yang telah divalidasi ahli. Angket respon siswa hanya diberikan kepada siswa di kelas eksperimen. Adapun teknis analisis data tes yang digunakan pada penelitian ini adalah uji normalitas, uji homogenitas, dan uji hipotesis. Sementara, analisis data non tes berupa angket respon siswa pada penelitian ini mengacu pada skala Likert.

\section{HASIL DAN PEMBAHASAN}

Berdasarkan perhitungan statistik diperoleh beberapa nilai pemusatan dan penyebaran data dari hasil pretest dan posttess. Rekapitulasi data hasil pretest dan posttest untuk kelas kontrol dan kelas eksperimen dapat dilihat pada table 1 berikut ini:

TABEL 1. Rekapitulasi Data Hasil Pretest dan Posttest pada Kelas Kontrol dan Kelas Eksperimen

\begin{tabular}{clcccc}
\hline \multirow{2}{*}{ No. } & \multirow{2}{*}{$\begin{array}{c}\text { Pemusatan dan } \\
\text { Penyebaran Data }\end{array}$} & \multicolumn{2}{c}{ Pretest } & \multicolumn{2}{c}{ Posttest } \\
\cline { 3 - 6 } & Kelas Kontrol & $\begin{array}{c}\text { Kelas } \\
\text { Eksperimen }\end{array}$ & Kelas Kontrol & $\begin{array}{c}\text { Kelas } \\
\text { Eksperimen }\end{array}$ \\
\hline 1 & Nilai Terendah & 15 & 10 & 33 & 35 \\
2 & Nilai Tertinggi & 63 & 60 & 98 & 100 \\
3 & Rata-rata & 32,13 & 30,28 & 62,77 & 69,44 \\
4 & Modus & 38 & 33 & 75 & 70 \\
5 & Median & 33 & 30 & 65 & 70 \\
6 & Standar Deviasi & 10,44 & 12,42 & 15,34 & 13,63 \\
\hline
\end{tabular}

Hasil perhitungan uji hipotesis untuk penelitian ini disajikan dalam tabel 2 berikut:

\begin{tabular}{lcc}
\multicolumn{2}{c}{ TABEL 2. Hasil Perhitungan } & Uji Hipotesis \\
\hline Statistik & Pretest & Posttest \\
\hline $\mathrm{t}_{\text {hitung }}$ & 0.71 & 2.00 \\
$\mathrm{t}_{\text {tabel }}$ & \multicolumn{2}{c}{1.99} \\
Kesimpulan & Ha ditolak & Ha diterima \\
\hline
\end{tabular}

Sementara, hasil perhitungan angkat respon siswa terhadap soal dalam format animasi dapat dilihat pada tabel 3 di bawah ini:

\begin{tabular}{crcc} 
& \multicolumn{2}{c}{ TABEL 3. Hasil Angket Respon Siswa terhadap Soal dalam Format Animasi } \\
\hline No. & Indikator Angket & Persentase & Kategori \\
\hline 1 & Penyajian soal dalam format animasi & $86,54 \%$ & Baik Sekali \\
2 & Pengaruh pada kemampuan berpikir reflektif & $75,64 \%$ & Baik \\
& Rata-rata & $81,09 \%$ & Sangat Baik \\
\hline
\end{tabular}


Adapun, hasil analisis Kemampuan berpikir Reflektif pada kelas kontrol dan kelas eksperiman dapat dilihat dari hasil pretest dan posttest pada gambar 1 berikut ini:

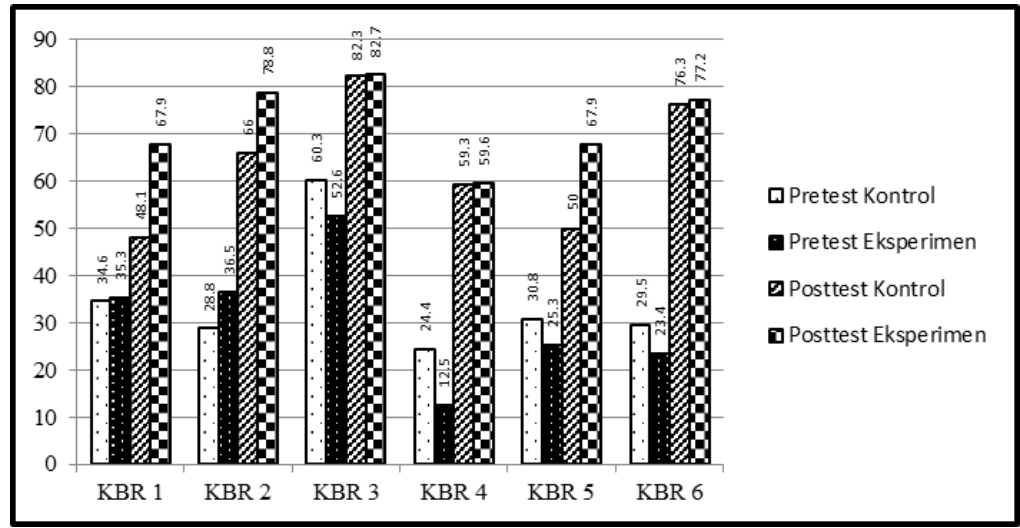

GAMBAR 1. Diagram Hasil Pretest dan Posttest Kemampuan Berpikir Reflektif Siswa pada Kelas Kontrol dan Kelas Eksperimen

Berdasarkan hasil penelitian di atas, kita dapat mengetahui jika nilai yang didapatkan oleh kelas kontrol dan kelas eksperimen pada saat posttest menunjukkan peningkatan nilai yang lebih baik. Artinya, metode drill dapat meningkatkan kemampuan berpikir reflektif. Meskipun sama-sama meningkat, tetapi peningkatan nilai posttest pada kelas eksperimen lebih tinggi dibandingkan kelas kontrol, hal ini menunjukkan bahwa kemampuan berpikir reflektif kelas eksperimen menjadi jauh lebih baik dibanding kelas kontrol. Hal ini sejalan dengan penelitian yang dilakukan oleh Jemi Haryadi yang menyimpulkan bahwa hasil tes pemahaman konsep siswa yang menggunakan butir soal dalam format animasi lebih baik dibandingkan siswa yang menggunakan butir soal dalam format cetak (Heryadi, 2012).

Latihan soal dalam format animasi membuat latihan soal menjadi lebih bervariasi. Dengan variasi, maka kebosanan dapat dikurangi atau bahkan dihilangkan (Ibrahim \& Syaodih , 2012). Artinya, kelemahan metode drill yang bersifat membosankan pun dapat teratasi karena soal latihan dalam format animasi lebih diminati siswa dibanding soal dalam format cetak. Sesuatu yang diminati atau menarik perhatian akan membuat siswa bersungguh-sungguh dalam belajar (Ibrahim \& Syaodih , 2012).

Jika dilihat lebih rinci, pada saat pretest kelas kontrol lebih unggul dibanding kelas eksperimen pada hampir setiap indikator kemampuan berpikir reflektif (KBR). Setelah diberi perlakuan, keadaannya menjadi terbalik, yaitu kelas eksperimen unggul di setiap kemampuan berpikir reflektif. Keunggulan pada kelas eksperimen ini terjadi karena dengan soal dalam format animasi, siswa dapat memahami dengan baik maksud dari soal sehingga peluang mereka untuk menjawab benar lebih besar dibanding kelas kontrol yang hanya menggunakan latihan dalam format cetak Unggulnya kelas eksperimen yang menggunakan metode drill berbantuan soal animasi ini diperkuat melalui perolehan angket siswa pada indikator kemampuan berpikir reflektif yang mendapatkan respon baik. Data tersebut memberikan gambaran bahwa latihan soal dalam format animasi yang digunakan dalam pembelajaran mendapatkan respon yang baik dari siswa dalam meningkatkan kemampuan berpikir reflektif.

Kemampuan berpikir reflektif siswa pada kelas eksperimen meningkat karena siswa memiliki kemampuan yang baik dalam memahami maksud dari soal. Hal ini sejalan dengan pernyataan Andi Suhandi yang menyatakan bahwa soal dalam format animasi dapat memperjelas maksud dari soal dan meminimalkan kesalahan interpretasi (Suhandi, 2011). Selain itu, soal-soal yang dianimasikan dapat lebih memberikan gambaran tentang persoalan yang ditanyakan, memahami maksud dan isi soal, serta gambaran masalah menjadi lebih jelas. Apabila siswa dapat memahami soal dengan baik dan jelas, maka siswa akan lebih mudah menyelesaikan persoal dengan baik pula, sehingga kemampuan berpikir reflektif siswa akan semakin baik dan meningkat.

Berdasarkan hasil penelitian di atas, pembelajaran dengan metode drill berbantuan soal animasi pada penelitian kali ini dapat membuat kemampuan berpikir reflektif kelas eksperimen jauh lebih 
unggul dibanding kelas kontrol pada kemampuan mendeskripsikan (KBR 1), mengidentifikasi (KBR 2), dan memprediksi (KBR 5). Kemampuan mendeskripsikan (KBR 1) dan kemampuan mengidentifikasi (KBR 2) pada kelas eksperimen lebih unggul dibanding kelas kontrol karena pada saat pembelajaran kelas eksperimen terbiasa dengan soal-soal dalam format animasi. Soal dalam format animasi dibuat dengan tampilan yang berwarna. Tampilan warna lebih disukai dibanding tampilan hitam putih (Smaldino, 2012). Tampilan warna akan mempertegas gambar, sehingga terlihat seperti benda aslinya. Unsur warna juga akan lebih lama diingat karena ingatan terhadap warna disimpan di otak kanan yang memiliki daya ingat jangka panjang (Windura, 2008). Hal ini membuat siswa lebih mudah mengingat dan memvisualisasikan atau membayangkan keadaan dari setiap soal berdasarkan pengetahuan yang didapat sebelumnya. Apabila siswa sudah terbiasa membayangkan keadaan suatu soal, maka siswa dapat mendeskripsikan (KBR 1) dan mengidentifikasi (KBR 2) keadaan soal-soal, meskipun pada saat posttest soal-soal tersebut tidak dibuat dalam format animasi.

Selain kemampuan mendeskripsikan (KBR 1) dan mengidentifikasi (KBR 2) yang unggul, kelas eksperimen juga terlihat lebih unggul secara signifikan pada kemampuan memprediksi (KBR 5). Efek animasi pada soal membuat masalah lebih mudah dipahami. Apabila siswa dapat memahami masalah dengan baik, maka siswa akan memiliki kemampuan memprediksi yang lebih baik juga.

Sementara, untuk kemampuan berpikir reflektif pada indikator mengeinterpretasi (KBR 3), mengevaluasi (KBR 4) dan menyimpulkan (KBR 6) baik kelas kontrol dan kelas eksperimen tidak memiliki perbedaan yang signifikan. Kemampuan menginterpretasi (KBR 3) adalah suatu kemampuan yang menuntut siswa menafsirkan situasi masalah berdasarkan konsep yang terlibat di dalamnya. Jika dilihat dari penyajian soal, soal-soal latihan yang diberikan pada kelas kontrol sudah dilengkapi dengan gambar dan teks. Gambar soal dalam format cetak pada kelas kontrol bersifat statis tidak seperti gambar soal dalam format animasi pada kelas eksperimen yang besifat dinamis. Namun, soal-soal yang digunakan oleh kelas kontrol dan kelas ekperimen ini belum menggambarkan keadaan yang kontekstual. Hal ini membuat interpretasi siswa terhadap soal dalam format animasi hampir sama dengan interpretasi siswa terhadap soal dalam format cetak, sehingga kemampuan menginterpretasi (KBR 3) kelas eksperimen hampir sama dengan kelas kontrol.

Selain menginterpretasi (KBR 3), kelas kontrol dan kelas eksperimen juga memiliki kemampuan yang hampir sama pada mengevaluasi (KBR 4) dan menyimpulkan (KBR 6). Pada kedua kemampuan ini, siswa dituntut untuk menyelidiki kebenaran suatu argumen dan membuat keputusan secara umum mengenai suatu masalah menggunakan konsep yang sesuai. Oleh karena itu, siswa harus menggunakan seluruh kemampuan yang dimilikinya, salah satunya adalah kemampuan matematis. Kemampuan matematis dibutuhkan untuk menyelesaikan masalah fisika yang bersifat kuantitatif. Perhitungan matematis yang dilakukan oleh siswa sangatlah penting dalam menarik suatu keputusan dalam mengevaluasi (KBR 4) dan menyimpulkan (KBR 6). Berdasarkan informasi yang didapat, siswa pada kedua kelas memiliki kemampuan matematis yang hampir sama, sehingga kemampuan mengevaluasi (KBR 4) dan menyimpulkan (KBR 6) kedua kelas pun sama

Dari uraian di atas terlihat bahwa beberapa kemampuan berpikir reflektif siswa pada kelas eksperimen secara signifikan lebih unggul dibanding kelas kontrol. Hal ini juga didukung dengan hasil uji statistik yang menunjukkan $t_{\text {hitung }}>\mathrm{t}_{\text {tabel }}$. Artinya, penggunaan metode drill berbantuan soal animasi yang digunakan dalam penelitian ini terbukti berpengaruh terhadap kemampuan berpikir reflektif siswa pada konsep dinamika partikel.

\section{PENUTUP}

Hasil penelitian telah memperlihatkan bahwa metode drill berbantuan soal animasi terbukti berpengaruh terhadap kemampuan berpikir reflektif siswa pada konsep dinamika partikel. Hal ini terlihat dari hasil uji hipotesis yang menunjukkan nilai $t_{\text {hitung }}>t_{\text {tabel }}$. Hasil ini didukung juga oleh angket respon siswa yang menunjukkan bahwa siswa memberikan respon positif terhadap penggunaan soal dalam format animasi dengan kategori sangat baik. 


\section{UCAPAN TERIMAKASIH}

Terima kasih kepada semua pihak yang telah membantu dalam proses penelitian ini, terutama dosen ahli, kepala sekolah, guru, siswa-siswi dan keluarga besar SMAN 1 Karawang.

\section{REFERENSI}

[1] E. Rofiah, "Penyusunan Instrumen Tes Kemampuan Berpikir Tingkat Tinggi Fisika pada Siswa SMP," Jurnal Pendidikan Fisika, 2013., 2013.

[2] N. Paden, "What was I Thinking? Encouraging Reflective Thinking in the Classroom Through Exam Question Appeals," in Proceeding of ASBBS, 2008.

[3] Elianawati, R. D and S. J, "Kontribusi Pembelajaran Fisika Matematika dalam mengembangkan Kemampuan Pemecahan Masalah Calon Guru Fisika Melalui Keterampilan Berpikir Reflektif," in Prosiding Seminar Kontribusi Fisika, Bandung, 2013.

[4] H. G. Hullfish and P. G. Smith, Reflective Thinking, New York: Dodd, Mead \& Company, 1961.

[5] A. Y. Chen, Reflective Thinking and Deep Learning, dalam Teachers Handbook On Teaching Generic Thinking Skills, SIngapura: Prentice Hall, 2012.

[6] N. Roestiyah, Strategi Belajar Mengajar, Jakarta: Rineka Cipta, 2012.

[7] S. Djamarah and A. Zain, Strategi Belajar Mengajar, Jakarta: Rineka Cipta.

[8] B. E. Purnama, Konsep Dasar Multimedia, Yogyakarta: Graha Ilmu, 2013.

[9] J. Heryadi, "Pengaruh Pengunaan Butir soal Dalam Format Animasi Terhadap Hasil Tes Pemahaman Konsep Cahaya dan Kuantitas Miskonsepsi Siswa," Tidak dipublikasikan, Skripsi pada Universitas Pendidikan Indonesia, 2012.

[10] R. Ibrahim and N. Syaodih , Perencanaan Pengajaran, Jakarta: Rineka Cipta, 2012.

[11] A. Suhandi, "Pengaruh Format Soal dalam Bentuk Animasi Terhadap Validitas dan Reliabilitas Tes Pemahaman Konsep Pembiasan Cahaya," Berkala Fisika, 2011.

[12] S. E. Smaldino, Instructional Technology and Media For Learning, Jakarta: Kencana Prananda Media Grup, 2012.

[13] S. Windura, Brain Management Series For Learning Strategy: Mind Map Langkah Demi Langkah, Jakarta: Elexmedia Komputindo, 2008. 